\title{
3'-Biotin-tagged microRNA-27 does not associate with Argonaute proteins in cells
}

\author{
YANG ERIC GUO ${ }^{1,2}$ and JOAN A. STEITZ $2,3,4$ \\ ${ }^{1}$ Department of Cell Biology, ${ }^{2}$ Department of Molecular Biophysics and Biochemistry, and ${ }^{3}$ Howard Hughes Medical Institute, Boyer Center \\ for Molecular Medicine, Yale University School of Medicine, New Haven, Connecticut 06536, USA
}

\begin{abstract}
Synthetic 3'-biotin-tagged microRNAs (miRNAs) have often been used to select interacting messenger RNA (mRNA) and noncoding RNA (ncRNA) targets. Here, we examined the extent of association of $3^{\prime}$-end biotinylated miR-27 with Argonaute (Ago) proteins in transfected human cells using a coimmunoprecipitation assay followed by Northern blot analysis. We report that biotinylated miR-27 does not efficiently associate with Ago compared to unmodified miR-27. These results suggest that $3^{\prime}$-end biotin-modified miRNAs are questionable monitors of miRNA function in cells.
\end{abstract}

Keywords: microRNA; biotin; Argonaute

\section{INTRODUCTION}

MicroRNAs (miRNAs) are small regulatory RNAs that play important biological roles by modulating cellular protein production. The specificity of miRNA regulation is determined by base-pairing interactions between miRNAs and their target RNAs (Bartel 2009). In mammalian cells, imperfect duplexes with messenger RNAs (mRNAs) are formed by miRNAs associated with one of four Argonaute (Ago) family proteins (Ago 1, 2, 3, and 4), which are core components of RNA-induced silencing complexes (RISC). Conserved binding pockets in Ago proteins recognize both ends of a miRNA and are critical for formation of the miRNA-Ago complex (Kuhn and Joshua-Tor 2013). The MID and the PAZ domains recognize the $5^{\prime}$ phosphate and the $3^{\prime}$ hydroxyl at the ends of a miRNA, respectively. Because miRNAs bind to Ago proteins with very high affinity (Lima et al. 2009; Tan et al. 2009), coimmunoprecipitation of miRNAs from cell lysate by anti-Ago antibodies provides a good assessment of miRNA association with Ago.

Identification of mRNAs and noncoding RNAs (ncRNAs) targeted by miRNAs is critical for understanding miRNA function. Since the discovery of miRNAs, bioinformatic and biochemical methods have been developed for target identification (Thomas et al. 2010). Among them, a 3'-end biotintagged-miRNA-based approach has been used in many studies (Ørom and Lund 2007; Ørom et al. 2008; Nonne et al. 2010; Lal et al. 2011; Hansen et al. 2013). Specifically, synthet-

\footnotetext{
${ }^{4}$ Corresponding author

E-mail joan.steitz@yale.edu

Article published online ahead of print. Article and publication date are at http://www.rnajournal.org/cgi/doi/10.1261/rna.045054.114.
}

ic 3'-biotinylated miRNAs are transfected into cells, followed by selection with streptavidin affinity resin after cell lysis. Coselected RNAs are often interpreted by researchers as targets of a functional miRNA-Ago complex. Here, we use a coimmunoprecipitation assay to show that synthetic $3^{\prime}$-biotinylated miR-27 miRNAs transfected into human Jurkat $\mathrm{T}$ cells do not efficiently associate with Ago proteins, suggesting that biotinylated miRNAs are unlikely to assemble into functional RISC complexes.

\section{RESULTS}

We tested several otherwise identical synthetic miR-27 miRNAs modified at their $3^{\prime}$ ends with biotin moieties similar or identical to those used in published reports (Ørom and Lund 2007; Nonne et al. 2010; Lal et al. 2011). Biotin was covalently conjugated to the 3 -hydroxyl group on the ribose of the last nucleotide via three different linkers that vary in length and chemical composition (Fig. 1A).

We transfected either unmodified or biotinylated forms of miR-27 annealed to miR-27* (complementary to miR27) (see Fig. 1A) into Jurkat T cells, which express low levels of endogenous miR-27 (data not shown). The cells were harvested, washed, and lysed $24 \mathrm{~h}$ after transfection, and Ago complexes were immunoprecipitated with anti-panAgo antibodies (clone 2A8) (Nelson et al. 2007), which

\footnotetext{
(c) 2014 Guo and Steitz This article is distributed exclusively by the RNA Society for the first 12 months after the full-issue publication date (see http://rnajournal.cshlp.org/site/misc/terms.xhtml). After 12 months, it is available under a Creative Commons License (Attribution-NonCommercial 4.0 International), as described at http://creativecommons.org/licenses/ by-nc/4.0/.
} 
A

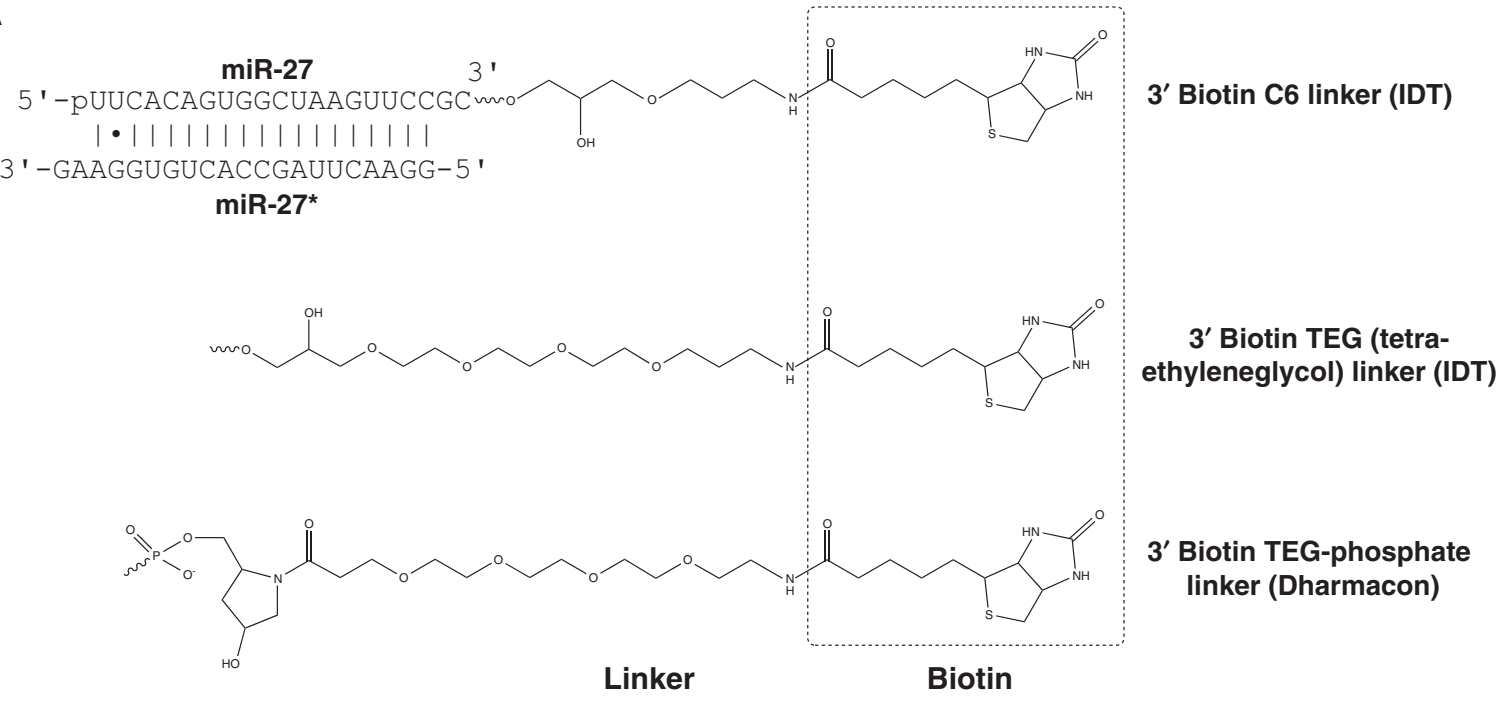

B

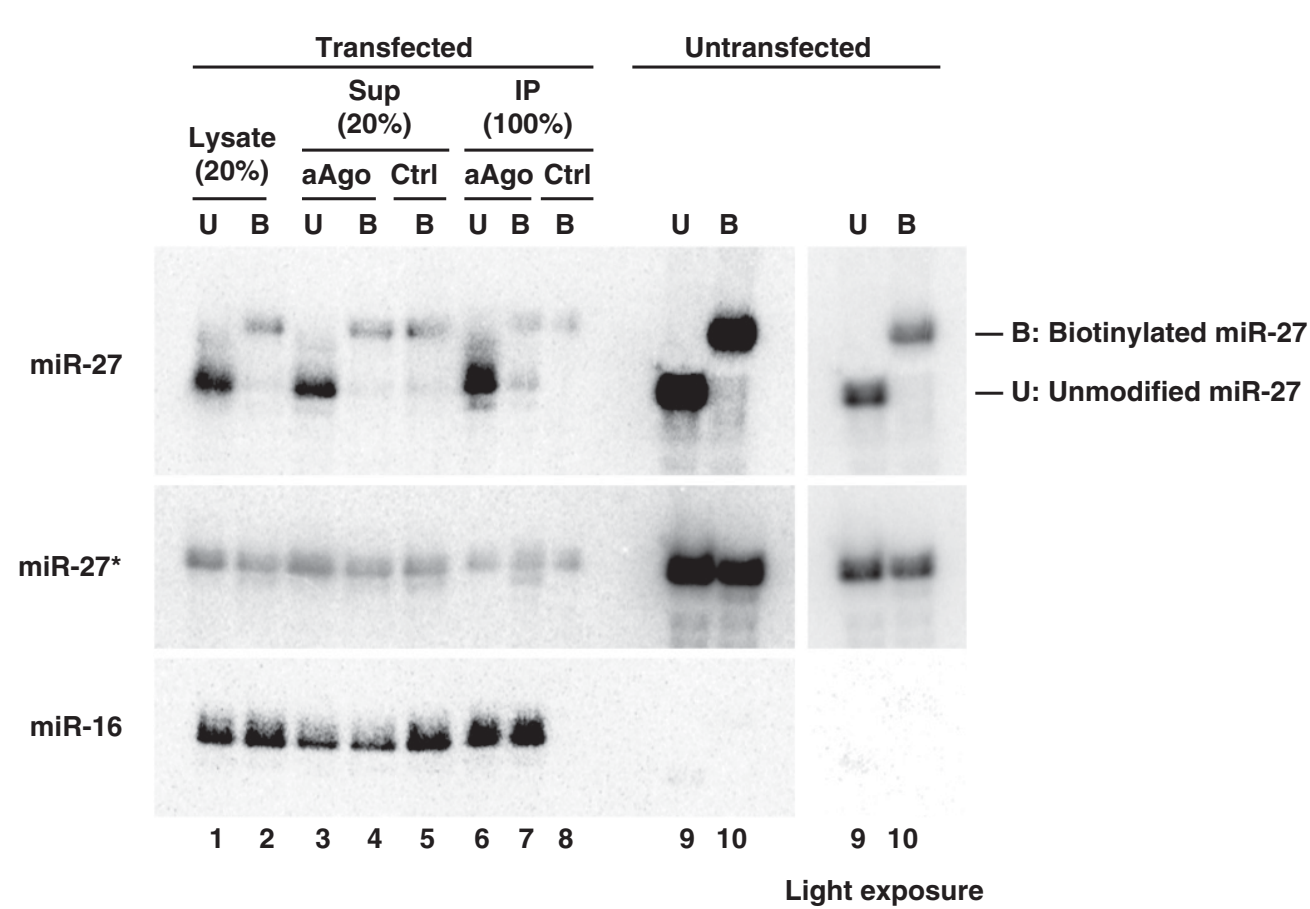

\begin{tabular}{c|cccc}
$\begin{array}{c}\text { Ago co-IP efficiency } \\
\text { IP/Lysate: }\end{array}$ & \multicolumn{3}{c}{ Lanes } \\
\cline { 2 - 5 } miR-27 & B & $\mathbf{6}$ & $\mathbf{7}$ & $\mathbf{8}$ \\
\hline \multirow{2}{*}{ U } & $32.8 \pm 5.3 \%$ & $34.2 \pm 3.7 \%$ & $1.4 \pm 0.3 \%$ \\
& miR-27 & $4.1 \pm 0.8 \%$ & $10.2 \pm 0.4 \%$ & $7.4 \pm 2.0 \%$ \\
miR-16 & $21.8 \pm 3.1 \%$ & $21.3 \pm 2.0 \%$ & $0.4 \pm 0.1 \%$ \\
\hline
\end{tabular}

FIGURE 1. Ago coimmunoprecipitation of 3'-biotin-tagged miR-27 miRNAs. (A) MiR-27 was chemically synthesized and covalently linked to a 3'-biotin moiety through three different linkers: C6, TEG, TEG-phosphate. Biotinylated miR-27 was annealed with a complementary strand, miR$27^{*}$, and the resulting double-stranded miRNA was transfected into human Jurkat T cells. A G•U wobble pair was introduced at the second nucleotide position of the miR-27 to ensure selective Ago loading (Ørom and Lund 2007). For the same reason, a 5' phosphate group (represented by "p") was added to miR-27 but not to miR-27*. (B) Northern blot analyses of miR-27, miR-27*, and miR-16 coimmunoprecipitated with anti-Ago ( $\alpha$ Ago) antibodies (lanes 6,7) or control antibodies (lane 8). Untransfected unmodified (U) and biotinylated (B) miR-27 provided markers (lanes 9,10). Input (lysate, 20\%), supernatant (Sup, 20\%), and immunoprecipitate (IP, 100\%) are shown. The results are representative of three independent experiments performed using 3'-biotin-miR-27 synthesized by Dharmacon. Comparable results were obtained for miR-27 modified with $3^{\prime}$-biotin (IDT) and $3^{\prime}$-biotin-TEG (IDT). Ago co-IP efficiencies = (intensity of bands in the IP)/(intensity of bands in the lysate). Values represent mean \pm standard deviations from three experiments. 
recognize Ago 1, 2, 3, and 4. Because the Ago epitope is at the $\mathrm{C}$ terminus, away from the binding pocket for the miRNA $3^{\prime}$ end (Nelson et al. 2007), 3'-biotin modifications should not interfere directly with antibody interaction. Levels of miR-27, miR-27*, and endogenous miR-16 present in the lysate, supernatant, and immunoprecipitated pellets were then analyzed by Northern blot (Fig. 1B). We performed the experiment using several different lysis buffers and obtained comparable results (Materials and Methods) (Fig. 1B).

We found that unmodified and biotinylated miR-27 molecules entered cells with similar efficiencies (Fig. 1B, cf. lanes 1,2 to 9,10 , respectively). Biotin conjugation slowed the gel migration of miR-27 (Fig. 1B, cf. lane 1 to 2), as confirmed by streptavidin affinity pulldown assays (data not shown). As expected, unmodified miR-27 was efficiently coimmunoprecipitated from the cell lysate by anti-Ago antibodies ( $\sim 33 \%$ efficiency) (Fig. 1B, lane 6$)$. In contrast, the biotinylated miR-27 (with TEG-phosphate linker; Dharmacon) was coimmunoprecipitated ( $\sim 8 \%$ IP efficiency) only at background levels compared to an isotype-matched control antibody ( $\sim \%$ efficiency) (Fig. 1B, cf. lane 7 to 8 ; upper band labeled "B"). Only nonbiotinylated miR-27, present either as an impurity in the chemical synthesis or resulting from $3^{\prime}$-end degradation occurring during the experiment, was efficiently immunoprecipitated ( 34\%) by anti-Ago antibodies (Fig. 1B, cf. lane 7 to 8; lower band labeled "U").

\section{DISCUSSION}

Our data are in agreement with X-ray crystal structures and biophysical studies of the human Ago-miRNA complex. A number of conserved amino acid residues in the PAZ domain of Ago proteins use noncovalent interactions to recognize the 3'-hydroxyl group of miRNAs (Elkayam et al. 2012; Schirle and MacRae 2012). Mutations in these residues or bulky modifications that replace the $3^{\prime}$ hydroxyl group of miRNAs, such as propanediol, fluorescein, or puromycin, abolish interaction with Ago proteins (Ma et al. 2004). Interestingly, studies of Thermus thermophilus Ago suggest that the $3^{\prime}$ end of a miRNA can be released from its PAZ binding pocket when extensive base-pairing interactions between guide and target induce a conformational change in bacterial Ago. However, $3^{\prime}$-end recognition by Ago needs to occur prior to this conformational change (Wang et al. 2009).

In the literature, several studies have either (1) validated the biological activity of 3'-biotinylated miRNAs using reporters (containing perfectly complementary target sites) or known endogenous mRNA targets; or (2) confirmed association of biotinylated miRNAs by immunoprecipitation with antiAgo antibodies using quantitative real-time polymerase chain reaction (Q-PCR) (Ørom and Lund 2007; Lal et al. 2011). The results suggested that biotinylated miRNAs are associated to some extent with Ago and repress reporters and known targets similarly to unmodified miRNAs. These conclusions may be explained in several ways. First, because the assays used were indirect, the signals may be due to the presence of some nonbiotinylated miRNAs, originating either from impurities in the chemical synthesis or $3^{\prime}$-end degradation in vivo; when loaded onto Ago (Fig. 1B, lane 7; lower band labeled "U"), these nonbiotinylated miRNAs may repress artificial reporters or endogenous mRNA targets. Second, the TaqMan Q-PCR assay does not distinguish biotinylated from unmodified miRNAs (Chen et al. 2005); therefore, both species contribute to the quantitation. Third, although unlikely, biotinylated miRNAs may be loaded into Ago proteins that are in the particular conformation in which the $3^{\prime}$ end of miRNA is not bound by the PAZ binding pocket (Ma et al. 2004). In other studies, perfectly complementary siRNA duplexes biotinylated at both $3^{\prime}$ ends have been successfully used for affinity purification of RISC from HeLa cell extracts in vitro (Martinez et al. 2002). Here, because the efficiency of modification might have been $<100 \%$, perhaps RISC assembly intermediates were captured with 3'-biotin only on the passenger strand of double-stranded siRNAs loaded onto Ago.

As an alternative to $5^{\prime}$ or $3^{\prime}$ modification, adding biotin to internal sites in a miRNA could be considered for affinity selection. The central bases at miRNA positions $11-16 \mathrm{nt}$ are usually flexible in cocrystal structures (Elkayam et al. 2012; Schirle and MacRae 2012), suggesting that biotin or other modifications at these internal sites may be tolerated by not interfering with essential miRNA interactions.

\section{CONCLUSIONS}

Our results show that $3^{\prime}$-biotinylated miR-27 does not efficiently associate with Ago proteins in cells. Because Ago proteins interact with miRNAs in a non-sequence-specific way (Kuhn and Joshua-Tor 2013), our observations on biotinylated miR-27 are likely to hold true for other miRNAs. We conclude that many of the reported "targets" selected by biotinylated miRNAs likely form base-pairing interactions with the biotinylated miRNA independent of Ago. Thus, caution should be exercised when interpreting results from biotinylated miRNA-based pulldown assays. Direct experimental evidence is needed to validate miRNA-mRNA/ncRNA target interactions inside cells.

\section{MATERIALS AND METHODS}

\section{MiRNAs}

MiRNAs were chemically synthesized by several companies as noted in Figure 1A: unmodified miR-27: $5^{\prime}$-/phosphate/UUCACA GUGGCUAAGUUCCGC-3'; biotinylated miR-27: 5'-/phosphate/ UUCACAGUGGCUAAGUUCCGC/biotin/-3'; and miR-27*: $5^{\prime}-$ GGAACUUAGCCACUGUGGAAG-3'. MiR-27 and miR-27* were annealed prior to transfection according to Tuschl (2006). 


\section{Cell culture and transfection}

Jurkat T cells were grown in RPMI 1640 medium supplemented with $10 \%$ fetal bovine serum, $1 \times$ penicillin/streptomycin and 2 mM L-glutamine. Two million Jurkat $\mathrm{T}$ cells were transfected with 200 pmol synthetic miR-27, unmodified or biotinylated, per cuvette using the Amaxa Cell Line Nucleofector kit V (program $\mathrm{X}-05$ ) from Lonza. Cells were harvested $24 \mathrm{~h}$ post-transfection for anti-Ago immunoprecipitation.

\section{Ago coimmunoprecipitation assay}

Transfected cells were washed twice with $1 \times$ PBS and lysed in lysis buffer (150 mM NaCl, 50 mM Tris-Cl pH 7.5, 0.5\% NP-40, 1 mM DTT, EDTA-free protease inhibitor cocktail [Roche] and RNase inhibitor [Roche]) for $15 \mathrm{~min}$ on ice. The lysate was passed through a 25.5-gauge needle 20 times to ensure complete lysis, then spun at $16,000 \mathrm{~g}$ for $15 \mathrm{~min}$ at $4^{\circ} \mathrm{C}$. The second lysis buffer tested was composed of $100 \mathrm{mM} \mathrm{NaCl}, 5 \mathrm{mM} \mathrm{MgCl} 2,20 \mathrm{mM}$ Tris-Cl pH 7.5, $0.3 \% \mathrm{NP}-40,1 \mathrm{mM}$ DTT, EDTA-free protease inhibitor cocktail (Roche) and RNase inhibitor (Roche). Cells were lysed by passing through a p200 tip, incubated on ice for $5 \mathrm{~min}$, and spun at $10,000 \mathrm{~g}$ for $10 \mathrm{~min}$ at $4^{\circ} \mathrm{C}$. The supernatant was subjected to antiAgo immunoprecipitation as follows: Protein G beads (GE Healthcare) were exchanged into lysis buffer, blocked with $200 \mu \mathrm{g} / \mathrm{mL}$ glycogen, $100 \mu \mathrm{g} / \mathrm{mL}$ yeast carrier RNA, and $2 \mathrm{mg} / \mathrm{mL} \mathrm{BSA}(\mathrm{NEB})$ at $4^{\circ} \mathrm{C}$ for $30 \mathrm{~min}$ and washed twice in lysis buffer. About $30 \mu \mathrm{L}$ of the blocked beads were incubated with lysate (supernatant after the $16,000 \mathrm{~g}$ or $10,000 \mathrm{~g}$ spin) and $12 \mu \mathrm{g}$ of anti-Ago antibodies (clone 2A8) (Nelson et al. 2007) or isotype-matched mouse IgG antibodies as a control (anti-HA; clone 16B12; Covance) for $3 \mathrm{~h}$ at $4^{\circ} \mathrm{C}$ with rotation. The beads were washed 2-3 times with the lysis buffer before RNA extraction. RNAs were isolated from the lysate, the supernatant after immunoprecipitation, and the beads by proteinase $\mathrm{K}$ digestion at $65^{\circ} \mathrm{C}$ for $30 \mathrm{~min}$, phenol extracted, and ethanol precipitated.

\section{Northern blot analysis}

RNAs were separated on a $15 \%$ denaturing polyacrylamide gel and electrophoretically transferred to Hybond- $\mathrm{N}^{+}$membrane (GE Healthcare). Hybridization to $5^{\prime}-\left[\gamma^{-32} \mathrm{P}\right]$-labeled DNA oligonucleotide probes (miR-27: $5^{\prime}$-GCGGAACTTAGCCACTGTGAA-3'; miR-27*: 5'-CTTCCACAGTGGCTAAGTTCC-3'; miR-16: 5' CGCCAATATTTACGTGCTGCTA- $3^{\prime}$, from IDT) was carried out in ExpressHyb (Clontech) overnight at $30^{\circ} \mathrm{C}$ following the manufacturer's protocol. Membranes were then exposed to phosphor screens, which were scanned on a Storm 860 Phosphorimager (GE Healthcare).

\section{ACKNOWLEDGMENTS}

We thank Z. Mourelatos for anti-Ago antibodies (clone 2A8); K. Riley, K. Tycowski, D. Cazalla, M. Xie, other J. Steitz laboratory members, H. Lin, and A. Giraldez for thoughtful discussions and suggestions; K. Tycowski and J. Brown for critical comments on the manuscript; and A. Miccinello for editorial work. This work was supported by grant CA16038 from the NIH. The content is solely the responsibility of the authors and does not necessarily represent the official views of the NIH. J.A.S. is an investigator of the Howard Hughes Medical Institute.

Received March 2, 2014; accepted April 2, 2014.

\section{REFERENCES}

Bartel DP. 2009. MicroRNAs: target recognition and regulatory functions. Cell 136: 215-233.

Chen C, Ridzon DA, Broomer AJ, Zhou Z, Lee DH, Nguyen JT, Barbisin M, Xu NL, Mahuvakar VR, Andersen MR, et al. 2005. Real-time quantification of microRNAs by stem-loop RT-PCR. Nucleic Acids Res 33: e179.

Elkayam E, Kuhn CD, Tocilj A, Haase AD, Greene EM, Hannon GJ, Joshua-Tor L. 2012. The structure of human Argonaute-2 in complex with miR-20a. Cell 150: 100-110.

Hansen TB, Jensen TI, Clausen BH, Bramsen JB, Finsen B, Damgaard CK, Kjems J. 2013. Natural RNA circles function as efficient microRNA sponges. Nature 495: 384-388.

Kuhn CD, Joshua-Tor L. 2013. Eukaryotic Argonautes come into focus. Trends Biochem Sci 38: 263-271.

Lal A, Thomas MP, Altschuler G, Navarro F, O’Day E, Li XL, Concepcion C, Han YC, Thiery J, Rajani DK, et al. 2011. Capture of microRNA-bound mRNAs identifies the tumor suppressor miR-34a as a regulator of growth factor signaling. PLoS Genet 7: e1002363.

Lima WF, Wu H, Nichols JG, Sun H, Murray HM, Crooke ST. 2009. Binding and cleavage specificities of human Argonaute2. J Biol Chem 284: 26017-26028.

Ma JB, Ye K, Patel DJ. 2004. Structural basis for overhang-specific small interfering RNA recognition by the PAZ domain. Nature 429: 318-322.

Martinez J, Patkaniowska A, Urlaub H, Lührmann R, Tuschl T. 2002. Single-stranded antisense siRNAs guide target RNA cleavage in RNAi. Cell 110: 563-574.

Nelson PT, De Planell-Saguer M, Lamprinaki S, Kiriakidou M, Zhang P, O'Doherty U, Mourelatos Z. 2007. A novel monoclonal antibody against human Argonaute proteins reveals unexpected characteristics of miRNAs in human blood cells. RNA 13: 1787-1792.

Nonne N, Ameyar-Zazoua M, Souidi M, Harel-Bellan A. 2010. Tandem affinity purification of miRNA target mRNAs (TAP-Tar). Nucleic Acids Res 38: e20.

Ørom UA, Lund AH. 2007. Isolation of microRNA targets using biotinylated synthetic microRNAs. Methods 43: 162-165.

Ørom UA, Nielsen FC, Lund AH. 2008. MicroRNA-10a binds the $5^{\prime} \mathrm{UTR}$ of ribosomal protein mRNAs and enhances their translation. Mol Cell 30: 460-471.

Schirle NT, MacRae IJ. 2012. The crystal structure of human Argonaute2. Science 336: 1037-1040.

Tan GS, Garchow BG, Liu X, Yeung J, Morris JP IV, Cuellar TL, McManus MT, Kiriakidou M. 2009. Expanded RNA-binding activities of mammalian Argonaute 2. Nucleic Acids Res 37: 7533-7545.

Thomas M, Lieberman J, Lal A. 2010. Desperately seeking microRNA targets. Nat Struct Mol Biol 17: 1169-1174.

Tuschl T. 2006. Annealing siRNAs to produce siRNA duplexes. CSH Protoc doi: 10.1101/pdb.prot4340.

Wang Y, Juranek S, Li H, Sheng G, Wardle GS, Tuschl T, Patel DJ. 2009. Nucleation, propagation and cleavage of target RNAs in Ago silencing complexes. Nature 461: 754-761. 

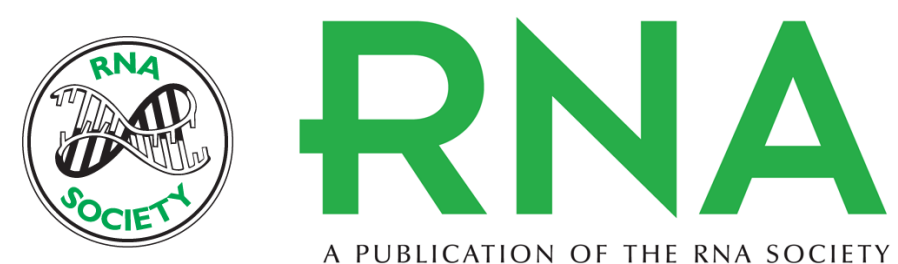

A PUBLICATION OF THE RNA SOCIETY

\title{
3'-Biotin-tagged microRNA-27 does not associate with Argonaute proteins in cells
}

Yang Eric Guo and Joan A. Steitz

RNA 2014 20: 985-988 originally published online May 12, 2014

Access the most recent version at doi:10.1261/rna.045054.114

\begin{abstract}
References This article cites 18 articles, 4 of which can be accessed free at: http://rnajournal.cshlp.org/content/20/7/985.full.html\#ref-list-1

Creative This article is distributed exclusively by the RNA Society for the first 12 months after the Commons full-issue publication date (see http://rnajournal.cshlp.org/site/misc/terms.xhtml). After 12 License months, it is available under a Creative Commons License (Attribution-NonCommercial 4.0 International), as described at http://creativecommons.org/licenses/by-nc/4.0/.
\end{abstract}

Email Alerting Receive free email alerts when new articles cite this article - sign up in the box at the Service top right corner of the article or click here. 